Article

\title{
Protective Effect of Potentilla glabra in UVB-Induced Photoaging Process
}

\author{
Long You $^{1} \mathbb{D}$, Mi-Yeon $\mathrm{Kim}^{2, *}$ and Jae Youl Cho ${ }^{1,3, * \mathbb{D}}$ \\ 1 Department of Integrative Biotechnology, and Biomedical Institute for Convergence at SKKU (BICS), \\ Sungkyunkwan University, Suwon 16419, Korea; youlonghc@gmail.com \\ 2 School of Systems Biomedical Science, Soongsil University, Seoul 06978, Korea \\ 3 Department of Biocosmetics, Sungkyunkwan University, Suwon 16419, Korea \\ * Correspondence: kimmy@ssu.ac.kr (M.-Y.K.); jaecho@skku.edu (J.Y.C.); Tel.: +82-31-290-7868 (J.Y.C.); \\ Fax: +82-2-824-4383 (M.-Y.K.)
}

check for updates

Citation: You, L.; Kim, M.-Y.; Cho, J.Y. Protective Effect of Potentilla glabra in UVB-Induced Photoaging Process. Molecules 2021, 26, 5408. https://doi.org/10.3390/molecules 26175408

Academic Editors: Chang-Gu Hyun and Jongsung Lee

Received: 23 August 2021

Accepted: 3 September 2021

Published: 6 September 2021

Publisher's Note: MDPI stays neutral with regard to jurisdictional claims in published maps and institutional affiliations.

Copyright: (c) 2021 by the authors. Licensee MDPI, Basel, Switzerland. This article is an open access article distributed under the terms and conditions of the Creative Commons Attribution (CC BY) license (https:// creativecommons.org/licenses/by/ $4.0 /)$.

\begin{abstract}
Maintaining skin homeostasis is one of the most important factors for skin health. UVBinduced skin photoaging is a difficult problem that has negative impacts on skin homeostasis. So far, a number of compounds have been discovered that improve human skin barrier function and hydration, and are thought to be effective ways to protect skin homeostasis. Potentilla glabra var. mandshurica (Maxim.) Hand.-Mazz. Ethanol Extract (Pg-EE) is a compound that has noteworthy anti-inflammatory properties. However, its skin-protective effects are poorly understood. Therefore, we evaluated the capacity of Pg-EE to strengthen the skin barrier and improve skin hydration. PgEE can enhance the expression of filaggrin (FLG), transglutaminase (TGM)-1, hyaluronic acid synthase (HAS)-1, and HAS-2 in human keratinocytes. Moreover, Pg-EE down-regulated the expression of pro-inflammatory cytokines and up-regulated the production of FLG, HAS-1, and HAS-2 suppressed by UVB through inhibition of p38 mitogen-activated protein kinase (MAPK) and extracellular signalregulated kinase (ERK) pathways. Given the above, since Pg-EE can improve skin barrier, hydration and reduce the UVB-induced inflammation on skin, it could therefore be a valuable natural ingredient for cosmetics or pharmaceuticals to treat skin disorders.
\end{abstract}

Keywords: AP-1; moisturizing; photoaging; Potentilla glabra var. mandshurica (Maxim.) Hand.-Mazz.; skin protection

\section{Introduction}

Skin is the largest organ in our body and has various distinct and complex functions. It is comprised of three distinct layers: epidermis, dermis and subcutis [1]. The epidermis is the outermost layer of the skin that acts as a barrier against damage from the environment, which includes pressure, micro-organisms, and radiation [2-4]. Keratinocytes make up nearly $95 \%$ of the epidermis. The stratum corneum (SC) is the outermost layer of the epidermis and has a pivotal role in maintaining skin barrier integrity and skin elasticity [5]. In studies of human skin, the improvement of skin barrier function and hydration are considered important factors for maintaining skin homeostasis. Imperfections in the skin barrier can lead to several skin diseases, such as allergies, atopic dermatitis, and infections [6]. As keratinocytes are the primary cell type in the skin barrier, the renewal of the SC derived from the proliferation of keratinocytes can limit skin damage and infections caused by environmental stressors.

Hydration affects SC flexibility, which further impacts the strength and elasticity of the skin [7-10]. The level of SC hydration is a crucial factor for skin barrier function [11]. The SC controls water loss from the epidermis by preventing water evaporation from the body. SC hydration can be determined by water on the outer surface and can be improved through the use of certain pharmaceuticals and cosmetics. Such bioactive compounds can form an occluding film that separates the SC from the surrounding environment [12]. 
Ultraviolet (UV) radiation is one of the most destructive exogenous factors for skin health. It can cause cellular damage and clinical consequences such as sunburn, photoaging, or even skin cancer [13]. According to its wavelength, UV can be classified into UVA (400-315 nm), UVB (315-280 nm), and UVC (280-100 nm). The shorter wavelengths are associated with more severe damage. However, because UVC is almost completely absorbed by the ozone layer and atmosphere, UVB is the most damaging electromagnetic radiation. Several studies have reported the harmful effects of UVB on skin, such as skin photoaging [14-16], DNA damage and increased oxidative stress [17,18], and skin inflammation through various mechanisms [19-22].

Various species of Potentilla have long been used in traditional medicine in Asia, Europe, and North America. Some Chinese conventional medicine books record that Potentilla glabra var. mandshurica (Maxim.) Hand.-Mazz. (Pg) was prescribed against microbial infection, inflammatory diseases, and chronic metabolic diseases [23,24]. In addition, extracts from Potentilla glabra exhibit antioxidant, antimicrobial, anti-inflammatory, and anti-ulcerogenic properties. Previously, the anti-inflammatory effects of Potentilla glabra ethanol extract and its molecular mechanism have been investigated [25]. In this paper, it was reported that the extract of Pg contains three major flavonoids, quercetin, kaempferol, and naringenin, that can suppress nitric oxide $(\mathrm{NO})$ production by reducing the phosphorylation of Src and ameliorate inflammatory symptoms in $\mathrm{HCl} / \mathrm{EtOH}$-induced gastritis. However, few studies have examined its functions at the cellular and molecular levels. Recently, a paper reported that Pg-EE played an anti-inflammatory role by targeting Src in NF- $\mathrm{KB}$ pathways, which reduced lipopolysaccharide (LPS)-induced inflammation in RAW264.7 cells as well as $\mathrm{HCl} / \mathrm{EtOH}$-induced gastritis in a mouse model [25]. In this paper, we examine the characteristics of Pg-EE in keratinocytes, which are a type of skin cell, under UVB irradiation.

\section{Results}

\subsection{Effects of Pg-EE on Cell Viability and Skin-Protective Activities}

Before evaluating the characteristics of Pg-EE, we tested the viability of $\mathrm{HaCaT}$ cells (human keratinocytes). Because the outermost layer and middle layer of the skin are epidermis and dermis, respectively [26], it was reasoned that if Pg-EE did not harm human keratinocytes, that would be a good indication that Pg-EE should not affect cell viability or have cytotoxic effects on skin-related cells. We used MTT assays to measure the cellular metabolic activities of HaCaT cells that were treated with Pg-EE. The MTT assay is a colorimetric assay wherein metabolically active cells can reduce MTT to purple formazan crystals. In other words, the darker purple the mixture solution is, the more active cells there are [27]. The cell viability results showed that Pg-EE did not damage $\mathrm{HaCaT}$ cells, and even promoted cell growth slightly in a dose-dependent manner from $0 \mu \mathrm{g} / \mathrm{mL}$ to $200 \mu \mathrm{g} / \mathrm{mL}$ (Figure 1a). The phytochemical components of Pg-EE were checked by LC-MS/MS (Figure 1c). Ten compositions were identified from the extract: (1) 3,4',5trihydroxy-3',7-dimethoxyflavanone and quercetagetin (RT: $1.07 \mathrm{~min}$ ), (2) quercetagetin6,7,3', $4^{\prime}$-tetramethyl ether (RT: $1.53 \mathrm{~min}$ ), (3) 4-O-methylepisappanol and kaempferol-3-O- $\beta$ D-glucopyranoside (RT: $2.99 \mathrm{~min})$, (4) ginkgetin, irisflorentin, mahuannin $\mathrm{H}$, and sulfuretin (RT: $3.42 \mathrm{~min}$ ), and (5) (3R,4S)-3,4-dihydroxy-3-(3', 4'-dimethoxybenzyl)-7-methoxy-chroman (RT: $6.91 \mathrm{~min}$ ), in addition to three major flavonoids, quercetin, kaempferol and naringenin, as previously reported [25]. 


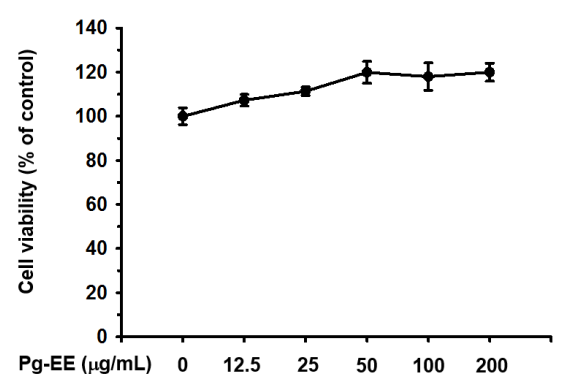

(a)

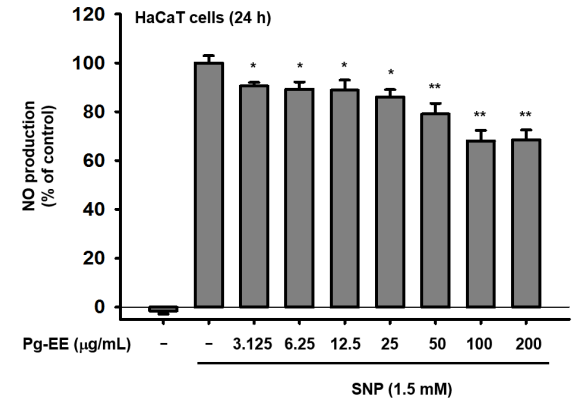

(b)
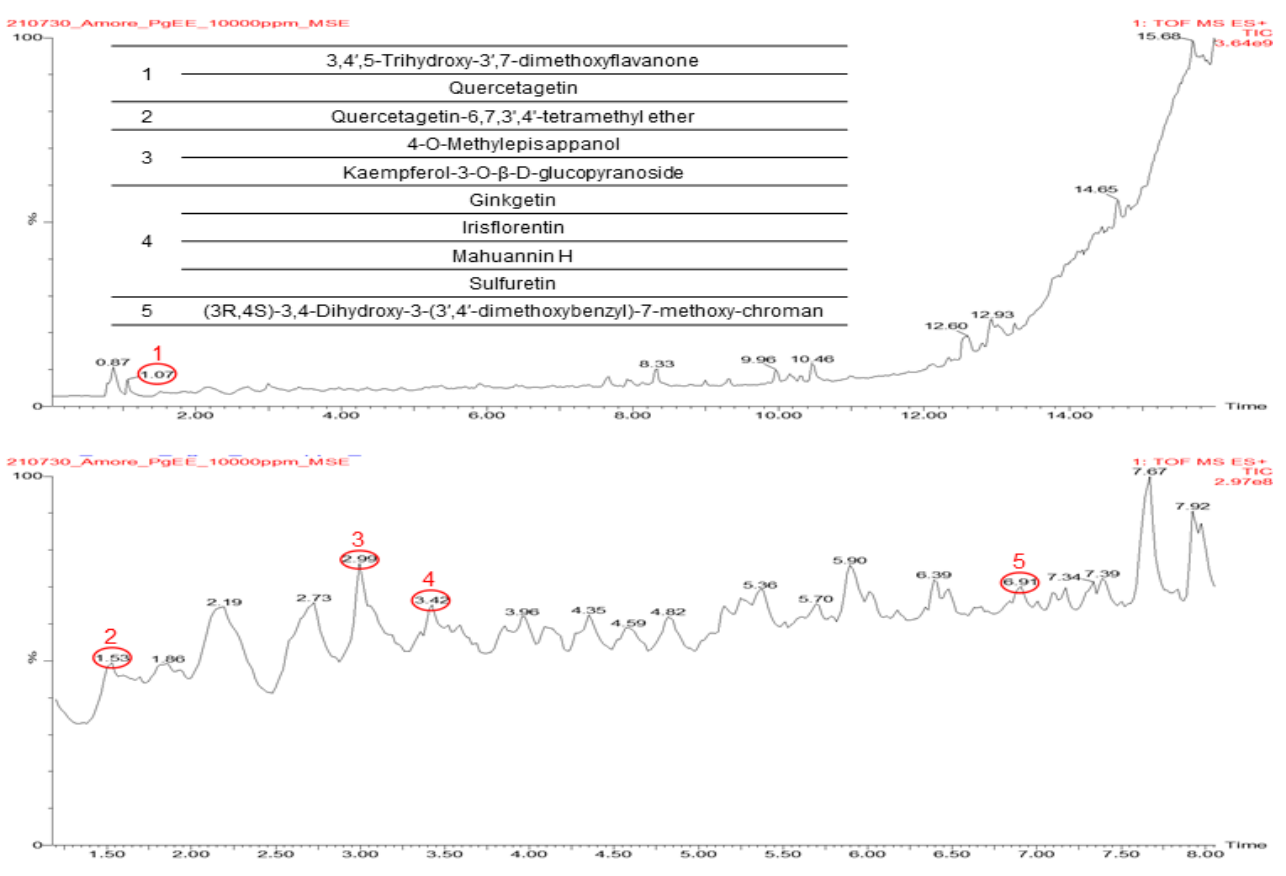

(c)

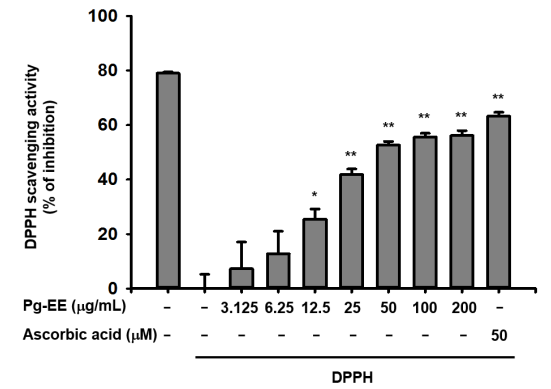

(d)

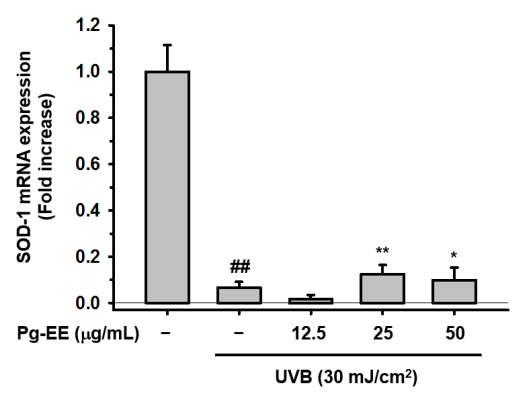

(f)

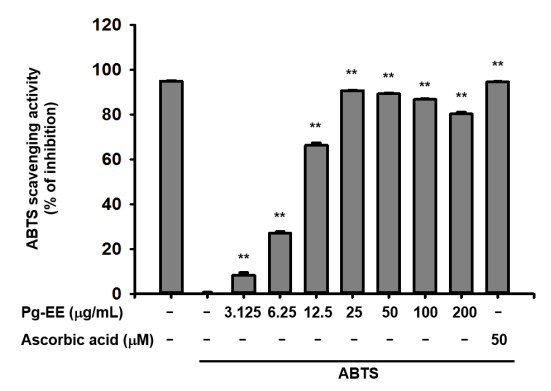

(e)

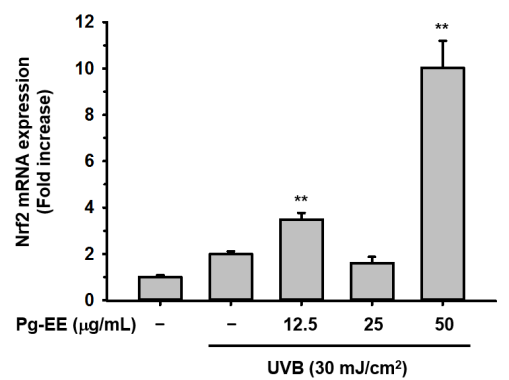

(g)

Figure 1. Cont. 


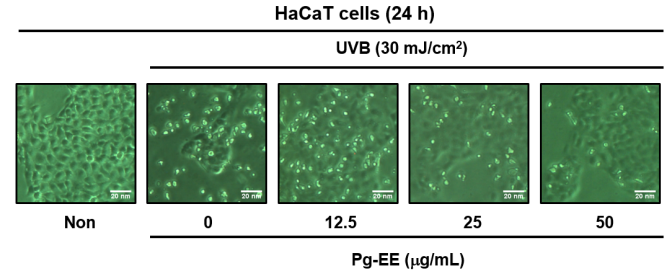

(h)

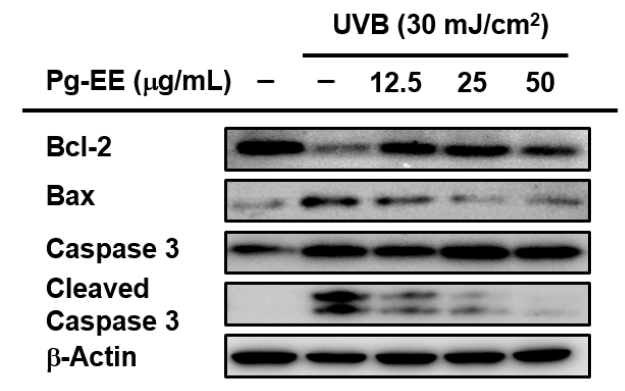

(j)

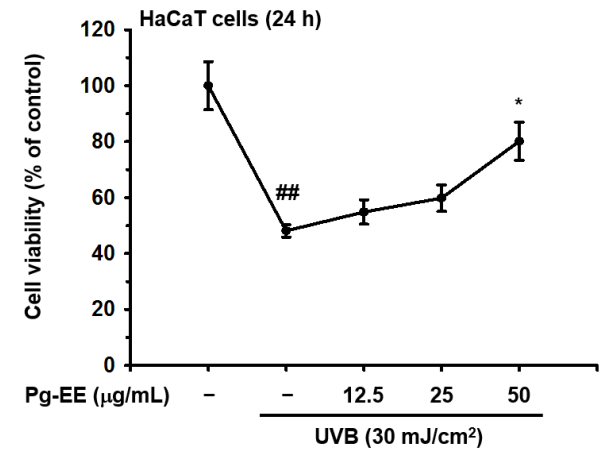

(i)

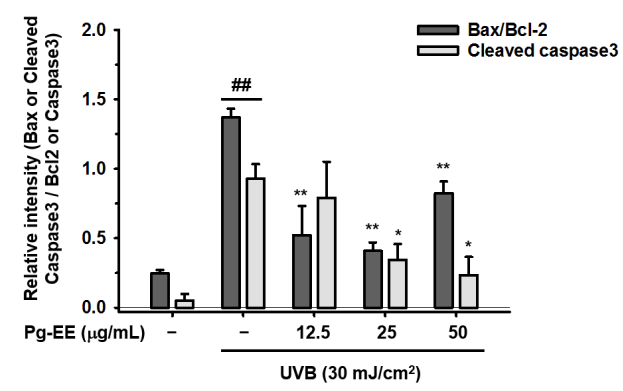

(k)

Figure 1. Effect of Pg-EE on cell viability and skin-protective abilities. (a) Cell cytotoxicity of HaCaT cells was checked by MTT assay. (b) NO assay was performed in HaCaT cells by coupling SNP (1.5 mM) together with Pg-EE treatments in a dose-dependent manner (3.125 to $200 \mu \mathrm{g} / \mathrm{mL}$ ). (c) Ingredients of Pg-EE were analyzed by LC-MS/MS spectrometry. (d) Cells were incubated with Pg-EE (3.125 to $200 \mu \mathrm{g} / \mathrm{mL})$ and $250 \mu \mathrm{M}$ DPPH at $37^{\circ} \mathrm{C}$ for $30 \mathrm{~min}$, then absorbance was measured at $517 \mathrm{~nm}$. Ascorbic acid $(50 \mu \mathrm{M})$ together with positive controls. (e) ABTS and potassium persulfate solution mixed together with dose-dependent Pg-EE ( 3.125 to $200 \mu \mathrm{g} / \mathrm{mL})$ in $37^{\circ} \mathrm{C}$ incubator for $30 \mathrm{~min}$. The absorbance of mixture solution was detected at $730 \mathrm{~nm}$. (f,g) HaCaT cells were pretreated with Pg-EE in a dose-dependent manner (12.5, 25, and $50 \mu \mathrm{g} / \mathrm{mL})$ for $30 \mathrm{~min}$ and irradiated with UVB $\left(30 \mathrm{~mJ} / \mathrm{cm}^{2}\right)$. After incubating for $12 \mathrm{~h}$, the mRNA levels of SOD-1 and Nrf2 were measured by real-time PCR. GAPDH was used as an internal control. (h) The morphology of HaCaT cells with Pg-EE treatment $(12.5,25$, and $50 \mu \mathrm{g} / \mathrm{mL})$ under UVB irradiation for $24 \mathrm{~h}$ was examined by microscopy. (i) Cell viability of HaCaT cells treated with Pg-EE $(12.5,25,50$, and $100 \mu \mathrm{g} / \mathrm{mL})$ under UVB irradiation $\left(30 \mathrm{~mJ} / \mathrm{cm}^{2}\right)$ for $24 \mathrm{~h}$ was measured by MTT assay. (j) Effect of Pg-EE on apoptosis of UVB-induced HaCaT cells was measured by immunoblotting analysis of active caspases. (k) The relative intensity of immunoblots (Bax, Bcl2, Cleaved Caspase 3, and Caspase 3) were measured by ImageJ. ${ }^{*} p<0.05$ and ${ }^{* *} p<0.01$ compared with control groups (SNP-treated group, only DPPH and ABTS group, only UVB group). \#\# $p<0.01$ compared with normal group.

Next, a nitric oxide (NO) donor, SNP [28,29], was added into HaCaT cells to induce $\mathrm{NO}$ production. After $24 \mathrm{~h}, \mathrm{Pg}$-EE slightly reduced the $\mathrm{NO}$ production and significantly decreased the NO at high concentrations (Figure 1c). Next, anti-oxidation activity of Pg-EE was examined using DPPH and ABTS assays. DPPH assays are used to evaluate the free radical scavenging ability of natural constituents [30]. Cells were treated with $\mathrm{Pg}$-EE in a dose-dependent manner from $0 \mu \mathrm{g} / \mathrm{mL}$ to $200 \mu \mathrm{g} / \mathrm{mL}$, and the data suggested a remarkable scavenging activity even at a low dose (Figure 1b). Another antioxidant test, the ABTS assay [31], also demonstrated clear effects of Pg-EE on free radical scavenging (Figure 1d). Superoxide dismutase 1 (SOD-1) is a free radical scavenging enzyme that can act against oxygen radical species in many kinds of circumstances. Nuclear factor erythroid 2-related factor 2 (Nrf2) is an important regulator for antioxidant and cellular protective. After the HaCaT cells were irradiated by UVB, Pg-EE was able to slightly recover the mRNA level of $S O D-1$ at 25 and $50 \mu \mathrm{g} / \mathrm{mL}$ (Figure 1e). Moreover, there was a significant enhancement of Nrf2 at $50 \mu \mathrm{g} / \mathrm{mL}$ (Figure 1f), which showed that Pg-EE has good characteristics against oxidation induced by UVB irradiation. Then, to evaluate 
the protective effects of Pg-EE against photodamage, the morphology of HaCaT cells treated with Pg-EE was examined after irradiation with UVB at $30 \mathrm{~mJ} / \mathrm{cm}^{2}$. Microscopy revealed that $\mathrm{HaCaT}$ cells that were only irradiated by UVB exhibited a round shape and floated on the media, which comprised the dead cells induced by UVB, compared with normal cells. However, treatment with Pg-EE reduced the occurrence of these floating round-shaped dead cells (Figure 1g). Additionally, MTT cell viability assays demonstrated that Pg-EE effectively reduced UVB-induced death of HaCaT cells (Figure 1h), which corresponded to a previous observation. To determine how Pg-EE could protect the HaCaT cells from UVB irradiation, cell death-related mechanisms were studied. Interestingly, Pg-EE relieved the UVB irradiation-induced cell death through anti-apoptosis (Figure 1i). It is well known that UVB can induce DNA damage and inflammation in cells [32]. It has also been shown that UVB irradiation can lead to apoptosis in keratinocytes [33]. B-cell lymphoma 2 (Bcl-2) and Bcl-2-like protein 4 (Bax) are the major players of the Bcl-2 family that participate in regulating apoptosis [34,35]. Bax has pro-apoptotic roles, whereas Bcl-2 can inhibit the activity of Bax to prevent apoptosis [36-38]. Thus, the ratio of Bax and Bcl-2 can act as a marker of apoptosis susceptibility in keratinocytes damaged by UVB. Here, immunoblots showed that Pg-EE suppressed Bax expression in $\mathrm{HaCaT}$ cells exposed to UVB but recovered the Bcl-2 expression which reduced by UVB, suggesting that Pg-EE can help $\mathrm{HaCaT}$ cells resist UVB damage. In addition, caspase 3, which is a critical regulator and promoter of apoptosis [39], was cleaved during UVB-induced apoptosis. Meanwhile, Pg-EE relieved the cleavage of caspase 3 in a dose-dependent manner. The relative intensity of immunoblots was also measured (Figure 1j). Taken together, Pg-EE exhibited beneficial effects on decreasing NO production and an excellent anti-oxidative ability for free radical scavenging. Moreover, Pg-EE can prevent photodamaging and rescue keratinocytes from UVB irradiation through anti-apoptotic pathways.

\subsection{Anti-Inflammatory Abilities of Pg-EE in Keratinocytes under UVB Irradiation}

There are many papers reporting that UVB can elicit severe inflammatory responses leading to problems in skin [17,19,40-42]. UVB activates key enzymes like cyclooxygenase-2 $(\mathrm{COX}-2)$ and induces the production of many pro-inflammatory cytokines, such as interleukin$1 \beta(I L-1 \beta)$, interleukin 6 (IL-6), and tumor necrosis factor alpha (TNF- $\alpha$ ). COX-2 is an inflammation-associated enzyme that is triggered by these pro-inflammatory cytokines and mediators [43], which induces the inflammatory response. These inflammatory responses cause skin damage that results in skin aging $[44,45]$. Therefore, to test the effects of Pg-EE on anti-inflammatory abilities affected by photodamage, the mRNA and protein expression levels of $\mathrm{COX}$-2 were measured in $\mathrm{HaCaT}$ cells pre-treated with Pg-EE before exposure to UVB irradiation. After treatment with Pg-EE, the UVB-induced production of COX-2 was significantly reduced in a dose-dependent manner (Figure 2a,c). The relative intensity of COX-2 in mRNA and protein levels were measured (Figure 2b,d). Moreover, the mRNA levels of pro-inflammatory cytokines, such as $I L-1 \beta$ and $I L-6$, which are induced by photodamage, were also down-regulated by Pg-EE in a dose-dependent manner (Figure 2e). The relative intensity of $I L-1 \beta$ and $I L-6$ in mRNA levels were also checked (Figure 2f). Taken together, the high expression levels of pro-inflammatory enzyme and cytokines induced by UVB irradiation can be relieved by Pg-EE, indicating that Pg-EE has anti-photodamage activity. 


\begin{tabular}{ll} 
Pg-EE $(\mu \mathrm{g} / \mathrm{mL})-$ & \multicolumn{2}{c}{ UVB $\left(30 \mathrm{~mJ} / \mathrm{cm}^{2}\right)$} \\
\hline COX-2 & $-12.525 \quad 50$ \\
GAPDH & -
\end{tabular}

(a)

\begin{tabular}{|c|c|c|c|c|c|}
\hline \multirow[b]{2}{*}{ Pg-EE $(\mu \mathrm{g} / \mathrm{mL}$} & \multirow[b]{2}{*}{ L) - } & \multicolumn{4}{|c|}{ UVB (30 mJ/cm²) } \\
\hline & & - & 12.5 & 25 & 50 \\
\hline coX-2 & $=$ & 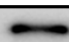 & 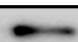 & 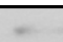 & \\
\hline B-Actin & & & & & \\
\hline
\end{tabular}

(c)

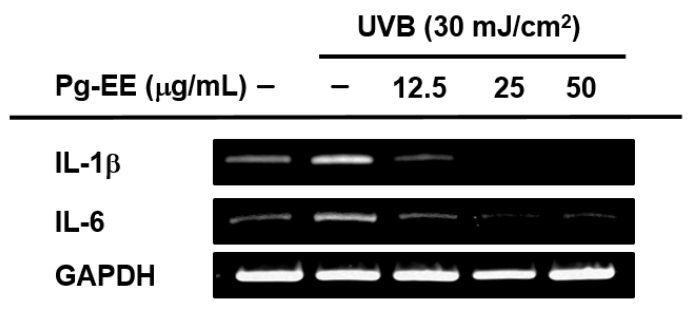

(e)

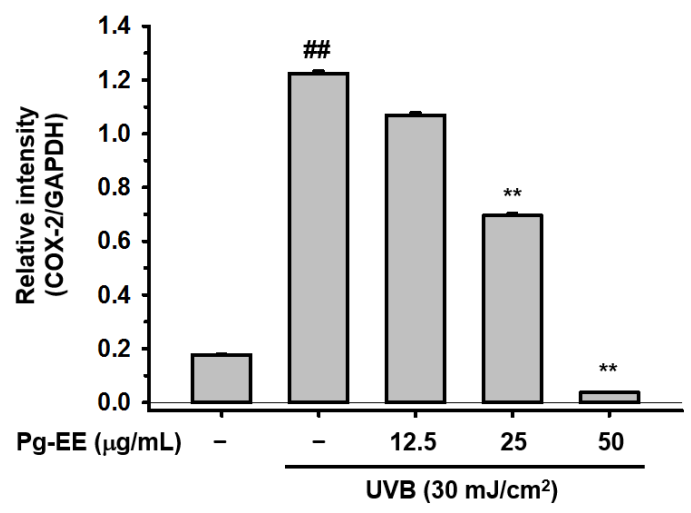

(b)

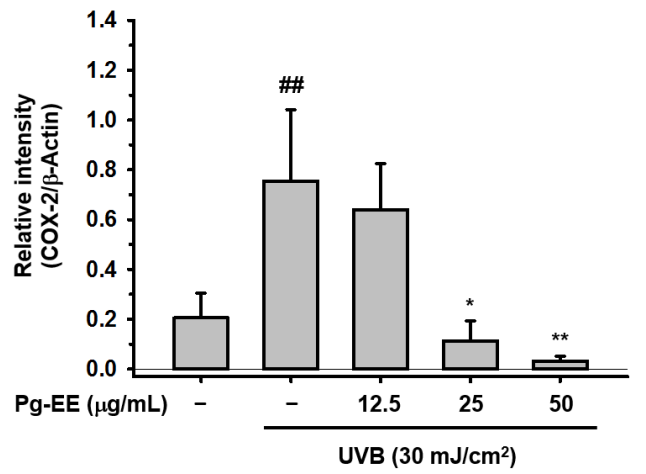

(d)

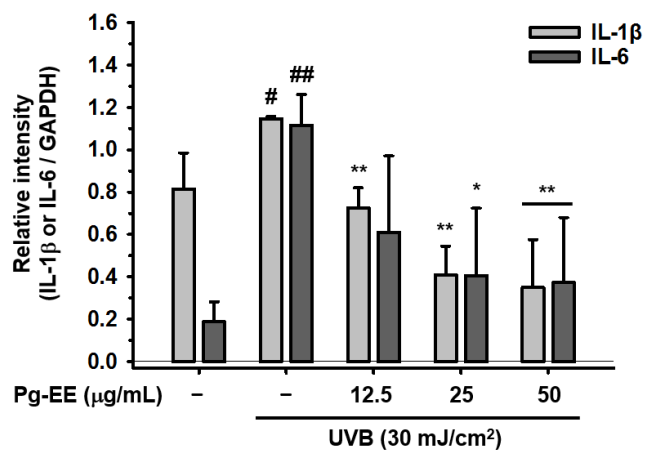

(f)

Figure 2. Anti-inflammatory abilities of Pg-EE in keratinocytes under UVB irradiation. (a) HaCaT cells were pretreated with Pg-EE in a dose-dependent manner $(12.5,25$, and $50 \mu \mathrm{g} / \mathrm{mL})$ for $30 \mathrm{~min}$ and irradiated with UVB $\left(30 \mathrm{~mJ} / \mathrm{cm}^{2}\right)$. The cell plates were then incubated for $6 \mathrm{~h}$. The mRNA level of COX-2 was measured by RT-PCR. (c) HaCaT cells were irradiated by UVB $\left(30 \mathrm{~mJ} / \mathrm{cm}^{2}\right)$ after pre-treatment with Pg-EE. Cells were then additionally incubated for $12 \mathrm{~h}$. The protein level of COX-2 in whole lysates was checked by immunoblotting analysis. (d) The relative intensity of immunoblot (COX-2) was measured by ImageJ. (e) HaCaT cells were pretreated with Pg-EE $(12.5,25$, and $50 \mu \mathrm{g} / \mathrm{mL}$ ) for 30 min, irradiated with UVB $\left(30 \mathrm{~mJ} / \mathrm{cm}^{2}\right)$, then incubated for $6 \mathrm{~h}$ in $37^{\circ} \mathrm{C}$ incubator. The mRNA levels of $I L-1 \beta$ and $I L-6$ were measured by RT-PCR. $(\mathbf{b}, \mathbf{f})$ The relative intensity of RT-PCR results $(C O X-2, I L-1 \beta$, and $I L-6)$ was measured by Image $.{ }^{*} p<0.05$ and ${ }^{* *} p<0.01$ compared with control groups (only UVB group). \# $p<0.05$ and \#\# $p<0.01$ compared with normal groups.

\subsection{Effect of Pg-EE on Skin Moisture Protection Activity}

As mentioned earlier, skin barrier and hydration are crucial for skin health. Thus, enhancing moisturizing factors has been the focus of many studies. There are many moisturizing factors, such as FLG, TGM-1, and HAS family members. Among these factors, FLG is an important epidermal protein that has an essential role in maintaining skin structure 
and function. It also has a pivotal impact on maintaining skin homeostasis [46]. In addition, TGM-1 is a membrane-associated gene that is highly expressed in the epidermis [47]. TGM-1 is involved in assembly of the cornified cell envelope, which has a protective role in forming the skin barrier. In particular, TGM-1 can synthesize strong bonds named cross-links among the structure proteins. These steady connections form the cornified cell envelope to make the epidermis stable $[48,49]$. Beside the skin barrier factors mentioned above, skin hydration factors such as HAS-1 and HAS-2 are also critical for skin health. HAS-1 and HAS-2 are isoenzymes that are capable of cellular hyaluronan production [50]. Most previous research has focused on HAS-2, whereas HAS-1 has received less attention. However, some recent papers have suggested that $H A S-1$ is related to human keratinocyte differentiation and is also correlated with the expression of HA, which indicates that HAS-1 has a crucial role in regulating skin homeostasis [51]. To investigate whether Pg-EE played a role in protecting moisture levels in human keratinocytes, Pg-EE was added to $\mathrm{HaCaT}$ cells in the presence or absence of UVB irradiation. The gene expression levels of skin barrier and hydration factors were measured by RT-PCR. Pg-EE enhanced the expression of FLG, TGM-1, HAS-1, and HAS-2 in a dose-dependent manner $(6.25,12.5$, and $25 \mu \mathrm{g} / \mathrm{mL})$ in the absence of UVB exposure (Figure 3a), whereas the expression of these moisturizing factors was inhibited at $50 \mu \mathrm{g} / \mathrm{mL}$ or higher doses (data not shown). Moreover, in the presence of UVB, the expression levels of $F L G, H A S-1$, and HAS-2 were significantly reduced compared to the normal condition. However, these expression levels recovered remarkably after treatment with $25 \mu \mathrm{g} / \mathrm{mL}$ Pg-EE (Figure 3c). The expression levels of these three moisturizing factors slightly increased with $50 \mu \mathrm{g} / \mathrm{mL}$ Pg-EE but to a lesser extent than seen with $25 \mu \mathrm{g} / \mathrm{mL}$ Pg-EE, possibly due to inhibitory effects of the higher dose (data not shown). The expression of TGM-1 also did not obviously recover from the exposure to UVB irradiation (data not shown). These data were confirmed by real-time quantitative PCR (Figure 3e). The relative intensity of corresponding mRNA levels conducted by RT-PCR was also measured (Figure 3b,d).

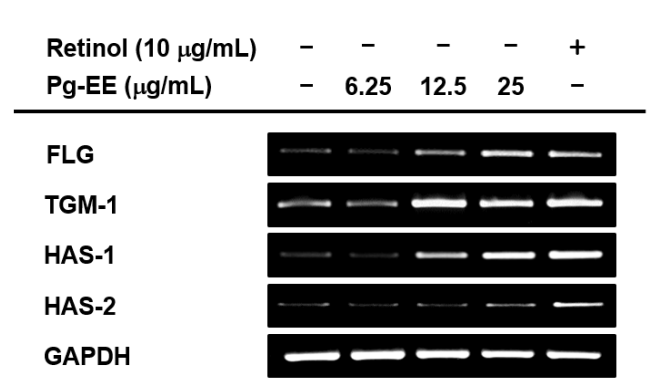

(a)

\begin{tabular}{|c|c|c|c|c|c|}
\hline \multirow[b]{2}{*}{ Pg-EE $(\mu \mathrm{g} / \mathrm{mL})$} & & \multicolumn{4}{|c|}{ UVB $\left(30 \mathrm{~mJ} / \mathrm{cm}^{2}\right)$} \\
\hline & L) - & - & 12.5 & 25 & 50 \\
\hline FLG & - & & - & - & - \\
\hline HAS-1 & - & - & - & - & - \\
\hline HAS-2 & - & 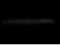 & $\ldots$ & 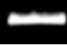 & 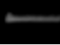 \\
\hline GAPDH & & & & & - \\
\hline
\end{tabular}

(c)

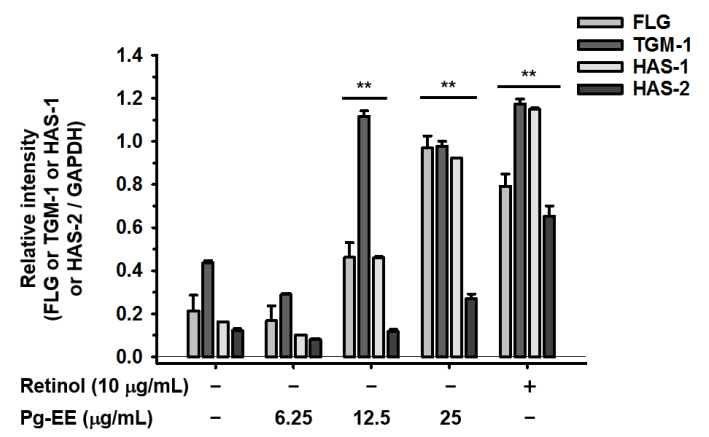

(b)

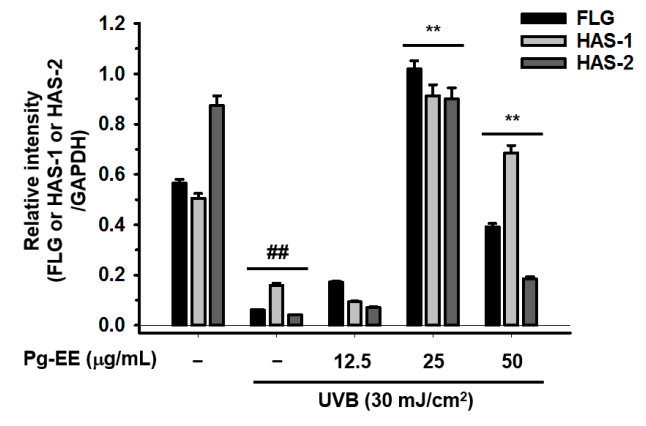

(d)

Figure 3. Cont. 


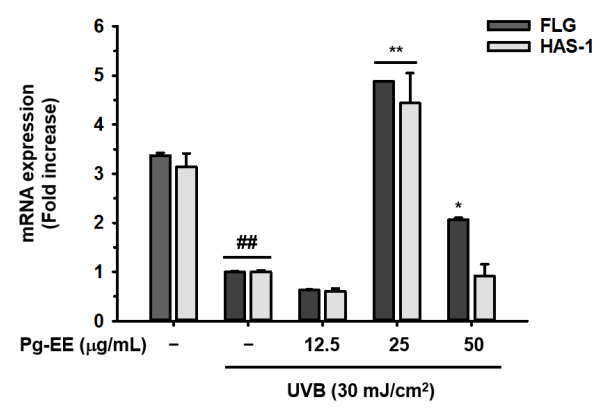

(e)

Figure 3. Effect of Pg-EE on skin moisture protective activity. (a) HaCaT cells were treated with Pg-EE (6.25, 12.5, and $25 \mu \mathrm{g} / \mathrm{mL})$ or retinol $(10 \mu \mathrm{g} / \mathrm{mL})$ for $6 \mathrm{~h}$. The mRNA levels of FLG, TGM-1, HAS-1, and HAS-2 were measured by RT-PCR. (c) HaCaT cells were pretreated with Pg-EE $(12.5,25$, and $50 \mu \mathrm{g} / \mathrm{mL})$ for $30 \mathrm{~min}$ and irradiated with UVB $\left(30 \mathrm{~mJ} / \mathrm{cm}^{2}\right)$. After incubation for $6 \mathrm{~h}$, the mRNA levels of FLG, HAS-1, and HAS-2 were measured by RT-PCR. (e) HaCaT cells were pretreated with Pg-EE $(12.5,25$, and $50 \mu \mathrm{g} / \mathrm{mL})$ for $30 \mathrm{~min}$ and irradiated with UVB $\left(30 \mathrm{~mJ} / \mathrm{cm}^{2}\right)$. After incubating for $6 \mathrm{~h}$, the mRNA levels of FLG and HAS-1 were measured by real-time PCR. GAPDH was used as an internal control. (b,d) The relative intensity of mRNA levels was measured using Image $.{ }^{*} p<0.05$ and ${ }^{* *} p<0.01$ compared with only UVB-irradiated groups. \#\# $p<0.01$ compared with normal groups.

\subsection{Pg-EE Shows Anti-Inflammatory and Moisture Protective Abilities via AP-1 Pathway under $U V B$}

Previously, studies have reported that UVB irradiation can induce the expression of inflammatory genes and suppress the production of moisturizing factor genes $[52,53]$. Thus, we examined whether Pg-EE displayed anti-inflammatory and moisture protective roles in human keratinocytes. We treated cells with AP-1 pathway-related inhibitorsSB203580 (a p38 inhibitor) at a dose of $20 \mu \mathrm{M}$, SP600125 (a JNK inhibitor) at $20 \mu \mathrm{M}$, and U0126 (an ERK inhibitor) at $10 \mu \mathrm{M}$-together with UVB irradiation. All three inhibitors reduced UVB-induced production of COX-2 (Figure 4a). Among the three inhibitors, SB203580 and U0126 exhibited stronger decreases than SP600125. Moreover, when we examined the moisturizing effects in UVB-irradiated keratinocytes, both SB203580 and U0126 prominently rescued the expression of FLG and HAS-1, which were suppressed by UVB irradiation before (Figure 4c). In addition, SP600125 and U0126 increased the expression of HAS-2. Together, these data suggest that p38 and ERK signaling pathways play dominant roles in anti-inflammatory and moisture-protective abilities. Next, we investigated signaling pathways upstream of p38 and ERK. In the p38 signaling pathway, UVB activated the phosphorylation of TAK1, mitogen-activated protein kinase (MKK) 3/6, and p38. The phosphorylation of MKK3/6 and p38 showed a dose-dependent decrease by treatment with Pg-EE. However, there was no big change in p-TAK1, indicating that TAK1 was the target of Pg-EE (Figure 4e). In addition, the ERK pathway was also checked by adding Pg-EE prior to UVB-irradiated HaCaT cells. UVB activated the phosphorylation of MAPK and ERK kinases (MEK)1/2 and ERK1/2, whereas phospho-ERK1 was reduced by Pg-EE, which demonstrated that Pg-EE targeted MEK1/2 to regulate the ERK signaling pathway (Figure 4g). In addition, c-Jun and c-Fos derived from the AP-1 signaling pathway were also suppressed by Pg-EE (Figure 4i). The relative intensity of mRNA levels determined by RT-PCR were measured (Figure $4 \mathrm{~b}, \mathrm{~d}$ ), and the relative intensity of immunoblots (p-TAK1, p-MKK3/6, p-p38, p-MEK1/2, p-ERK1/2, p-c-Jun, and p-c-Fos) was also tested, respectively (Figure $4 \mathrm{f}, \mathrm{h}, \mathrm{j}$ ). Taken together, Pg-EE down-regulated the expression of inflammatory genes and up-regulated the production of skin barrier and hydration genes through p38/ERK/AP-1 signaling pathways under UVB irradiation. 


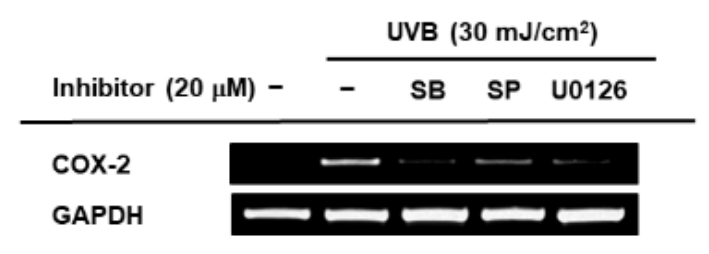

(a)

\begin{tabular}{lll} 
Inhibitor $(20 \mu \mathrm{M})-$ & \multicolumn{2}{c}{ UVB $\left(30 \mathrm{~mJ} / \mathrm{cm}^{2}\right)$} \\
\hline FLG & SB SP 00126 \\
HAS-1 & \\
HAS-2 &
\end{tabular}

(c)

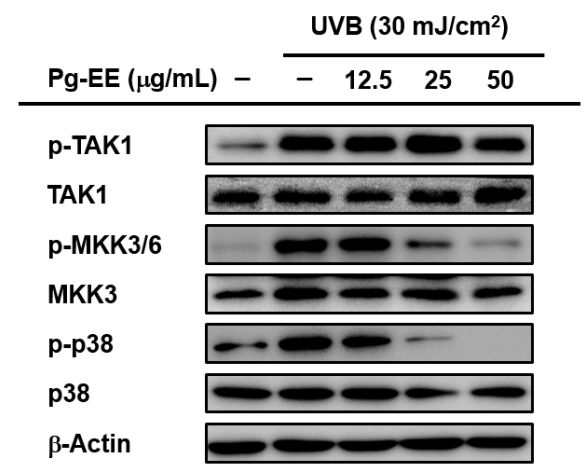

(e)

\begin{tabular}{ll} 
& \multicolumn{2}{c}{ UVB $\left(30 \mathrm{~mJ} / \mathrm{cm}^{2}\right)$} \\
\cline { 2 - 2 } Pg-EE $(\mu \mathrm{g} / \mathrm{mL})--12.525$ & -25 \\
\hline P-MEK1/2 \\
MEK1/2 \\
p-ERK1/2 \\
ERK1/2 \\
P-Actin
\end{tabular}

(g)

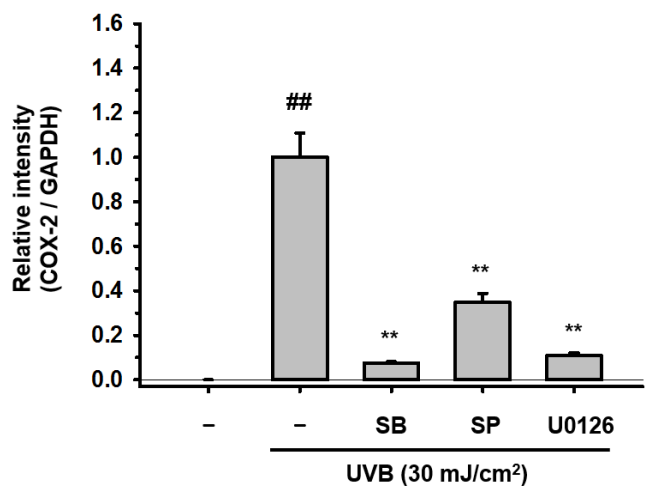

(b)

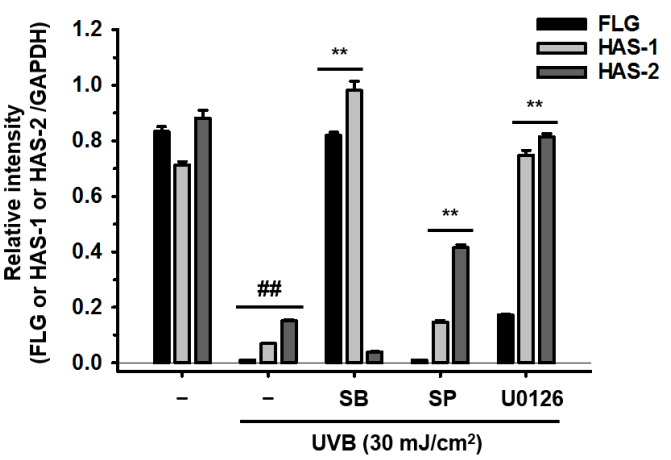

(d)

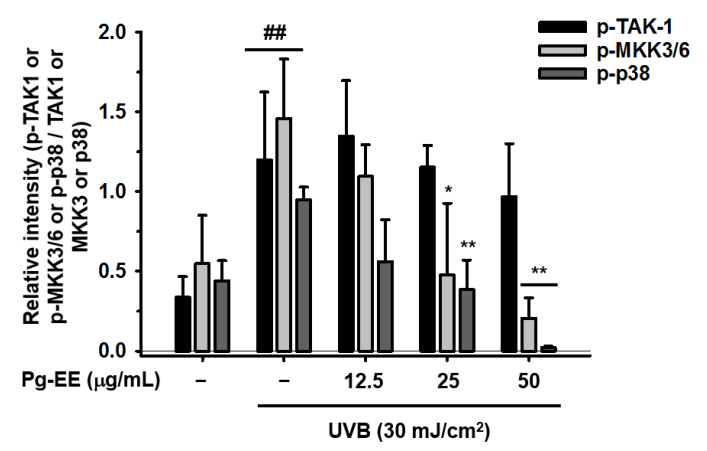

(f)

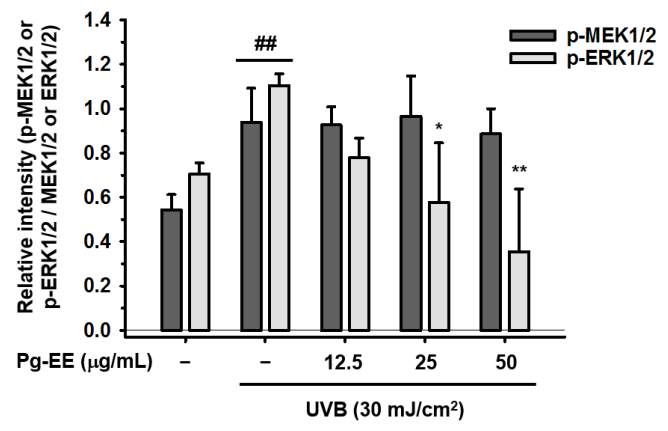

(h)

Figure 4. Cont. 


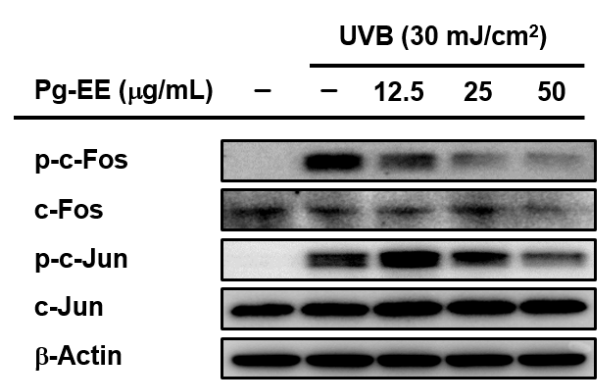

(i)

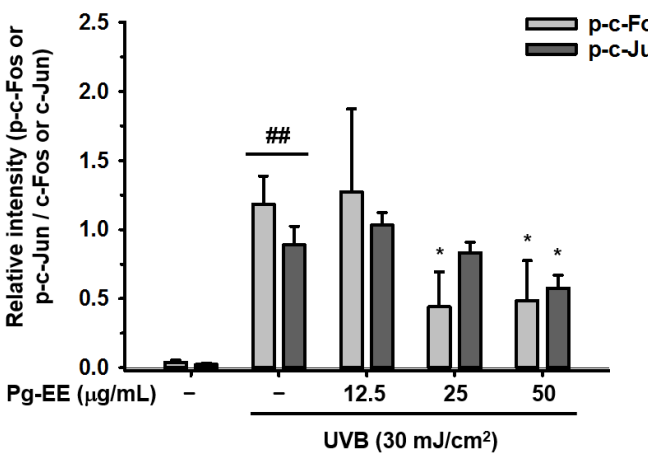

(j)

Figure 4. Pg-EE shows anti-inflammatory and moisture-protective abilities via AP-1 pathway under UVB irradiation. $(\mathbf{a}, \mathbf{c})$ HaCaT cells were pre-treated with MAPK inhibitors [SB203580 (a p38 inhibitor), SP600125 (a JNK inhibitor), and U0126 (an ERK inhibitor)] for $30 \mathrm{~min}$. Then, plates were irradiated with UVB (30 mJ/ $\left.\mathrm{cm}^{2}\right)$. After $6 \mathrm{~h}$, the mRNA levels of COX-2, FLG, HAS-1, and HAS-2 were measured by RT-PCR. (e,g) HaCaT cells were pre-treated with Pg-EE in a dose-dependent manner $(12.5,25$, and $50 \mu \mathrm{g} / \mathrm{mL})$ for $30 \mathrm{~min}$ and irradiated with UVB $\left(30 \mathrm{~mJ} / \mathrm{cm}^{2}\right)$. After incubating $12 \mathrm{~h}$, the protein levels of both phosphorylated and total forms of TAK1, MKK3/6, MEK1/2, p38, ERK1/2, $c$-Jun, and $c$-Fos were detected by immunoblotting analysis. (b,d,f,h-j) The relative intensity of mRNA (COX-2, FLG, HAS-1, and HAS-2) and protein levels (p-TAK1, p-MKK3/6, p-p38, p-MEK1/2, p-ERK1/2, p-c-Jun, and p-c-Fos) were measured by ImageJ. * $p<0.05$ and ${ }^{* *} p<0.01$ compared with control group (only UVB group). \#\# $p<0.01$ compared with normal group.

\section{Discussion}

Skin health is an important topic for clinical researchers. Among the focuses of such studies, moisturizing ability is one of the basic characteristics of cosmetic applications. As previously mentioned, UVB irradiation can cause a loss of skin moisture and induce inflammation. These bad influences can finally lead to the extrinsic skin aging called photoaging. Photoaging is a very complex change for human skin. There are two main factors that influence this process; one is skin type, and the other is ethnicity. First, photoaging more prevalently occurs in people whose skin is fair. Because people who have darker skin have more melanin content, which shows a more powerful ability to protect the skin from photo damage [54,55]. Second, ethnicity is also a predominant factor affecting pigmentary changes and the degree of wrinkles between white- and yellow-skinned people [56]. UVB is one of the primary ways that photoaging is induced. The cellular DNA located in the epidermis can absorb UVB irradiation, which causes skin damage, such as sunburn [56]. In addition, UV irradiation generates reactive oxygen species (ROS). ROS lead to oxidative damage in cell membranes or DNA. In clinical trials, photoaging causes a loss of translucency, laxity, wrinkles, inflammation, and so on [57]. Because of these, many treatments for photoaging have been developed by scientists in both topical and procedural interventions. The classical methods include topical retinoids, cosmeceuticals, injectable soft-tissue fillers, etc. [55].

Retinoids are a group of natural or synthetic compounds related to vitamin A, which can treat the mild or moderate photoaging. First, retinoids are pivotal for the differentiation of keratinocytes, the regeneration of the epidermis, and increasing the density of SC [58], which forms a thicker barrier to protect against UV irradiation. Second, retinoids enhance the production of collagen and improve elastic fiber, relieving not only wrinkles, but also the laxity of the skin $[59,60]$. Third, retinoids are beneficial in reducing the inflammation induced by photodamage by eliminating the release of pro-inflammatory cytokines [61]. 5-fluorouracil cream is also used for improving photoaging by increasing type 1 procollagen and activating dermal remodeling [62]. It can also accelerate the wound healing of injured epidermis.

Because of the ROS produced by UV irradiation, some antioxidants have also been proved to have anti-photoaging effects via scavenging the free radicals. Therefore, vitamin $\mathrm{C}$ and $\mathrm{E}$, coenzyme $\mathrm{Q}$, and lipoic acid have been confirmed to have high abilities in prevent- 
ing oxidation and photoaging [62]. Besides the single compounds, some natural extracts such as ginseng extracts also have antioxidant, anti-photoaging and anti-inflammatory abilities. A number of papers show that Korean red ginseng can relieve photoaging, increase the synthesis of collagen, and reduce skin inflammation [63]. Currently, people are paying great attention on their own skin health and there is increasing focus on natural products. Thus, finding a new herbal ingredient that simultaneously possesxes many different antiphotoaging properties in skin is an interesting area to study for researchers. The effects of keratinocytes irradiated with UVB have been reported by many papers. Cui et al. found that the ratio of Bcl-2 and Bax decreased, while p-ERK1/2 was up-regulated by UVB [64]. Chiu et al. demonstrated that the p38 signaling pathway was also involved in UVB-induced photoaging in keratinocytes [65]. Ko et al. also found that Nrf2 was suppressed by UVB and alleviated by ergothioneine [66]. All of these results were confirmed by our data in some ways. Pg is an attractive herb that mostly grows in mountainous areas. Therefore, in the past, people living near the mountains used Pg to treat colds, stomachaches, and especially irregular periods in women.

In our study, we found that Pg-EE not only has good antioxidant activity, but also protects skin against UVB irradiation, has good anti-inflammatory capacity, and helps skin retain moisture. Our data exhibited that Pg-EE improved skin hydrating effects by elevating moisturizing factors, which were inhibited by UVB before. Pg-EE can enhance the FLG, TGM-1, HAS-1, and HAS-2 in a dose-dependent manner alone. Whereas it can remarkably recover the FLG, HAS-1, and HAS-2 at a dose of $25 \mu \mathrm{g} / \mathrm{mL}$ in the presence of UVB, showing that Pg-EE can repair the loss of water of skin caused by UVB. Further study revealed that Pg-EE recovered the level of FLG by decreasing the phosphorylated MKK3/6/p38 pathway and gathered the expression of HAS-2 by downregulated the phosphorylation of ERK1/2 pathway. Both the decrease of p38 and ERK led to the re-accumulation of HAS-1. In addition, our study also illustrated that Pg-EE has a crucial role in skin protection because it can reduce the abnormal immune response and DNA damage caused by UVB. Pg-EE reduced the expression of COX-2, IL-1 $\beta$, and $I L-6$ by controlling the p38, ERK, and AP-1 pathway, while acting against apoptosis by restraining the ratio of Bax and Bcl-2. Because free radicals play an important role in inducing skin aging and oxidant activity can induce apoptosis, Pg-EE has both ideal antioxidant and anti-apoptotic activities, which means Pg-EE can be a potential anti-aging cosmetics ingredient. In summary, Pg-EE can enhance skin moisturizing levels and prevent keratinocytes from UVB-induced photodamage by suppressing the p38/ERK/AP-1 pathway, as well as by inhibiting apoptosis (Figure 5).

Taken together, because Pg-EE did not cause cytotoxicity, it becomes a potential remedy for use in preventing UVB-induced skin photoaging, and also has a high-efficiency moisturizing capacity. This is the first application of Pg-EE for human skin health protection. However, although Pg-EE exhibited a variety of skin-protecting properties, it still has undefined aspects that need to be solved in the future, such as stability of the Pg-EE compounds. In addition, whether Pg-EE has some other functions with respect to the skin, such as anti-melanogenesis, antioxidant, or anti-aging properties, remains to be further explored. Finally, since Pg-EE effectively prevents human keratinocytes from UVB photodamage and protects skin moisture, it is suggested that this extract could be applied in the development of a cosmeceutical product. 


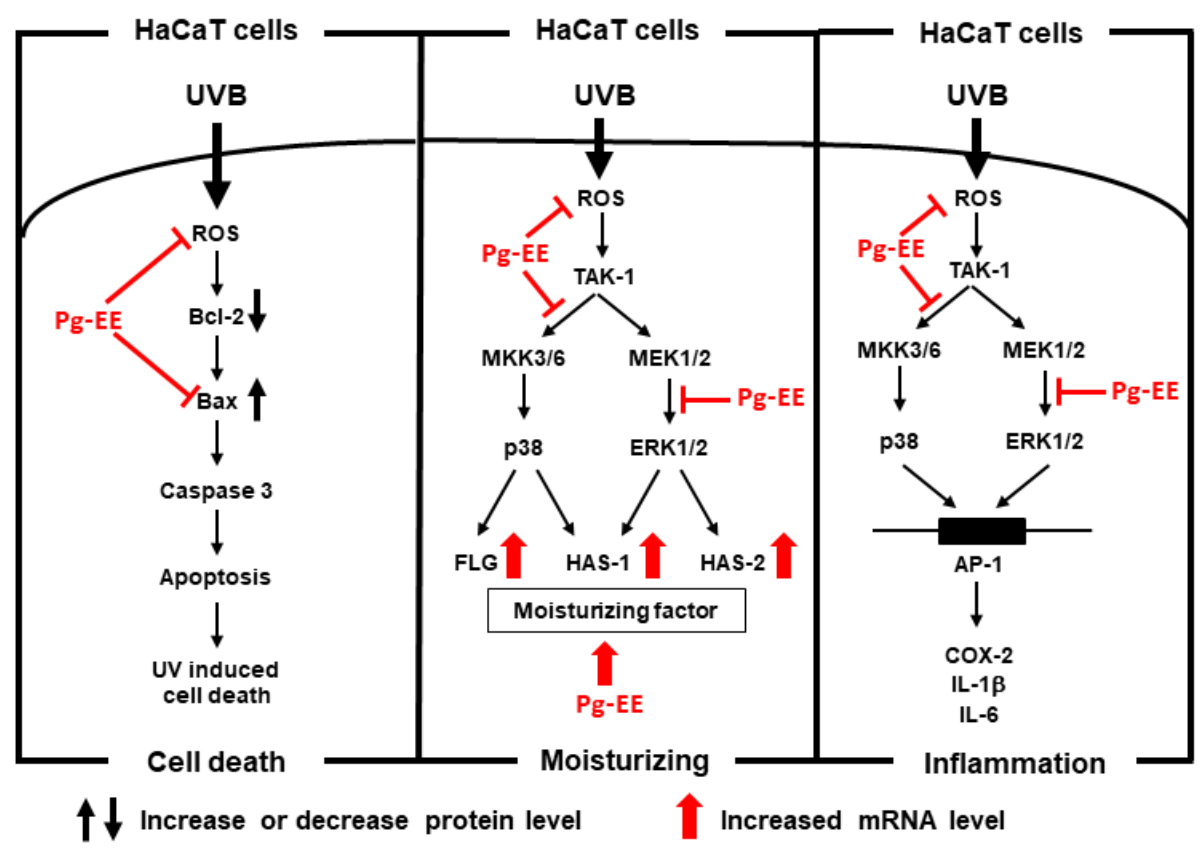

Figure 5. The schematic pathway of Pg-EE on skin protection against the photoaging process. The schematic illustration of Pg-EE-mediated skin-protective effects on the anti-photoaging process is summarized in terms of cell death, moisturizing, and inflammation.

\section{Materials and Methods}

\subsection{Materials}

The HaCaT (human skin keratinocyte) was purchased from the CLS Cell Lines Service GmbH (Eppelheim, Germany). 1,1-Diphenyl-2 picrylhydrazyl radical (DPPH), 2,2'-azinobis (3-ethylbenzothiazoline-6-sulfonic acid) diammonium salt (ABTS), sodium nitroprusside (SNP), (3-4,5-dimethylthiazol-2-yl)-2,5-diphenyl-tetrazolium bromide (MTT), dimethyl sulfoxide (DMSO), sodium dodecyl sulfate (SDS), and bovine serum albumin (BSA) were bought from Sigma (St. Louis, MO, USA). SB203580 (a p38 inhibitor), SP600125 (a JNK inhibitor) and U0126 (an ERK inhibitor) were also acquired from Sigma (St. Louis, MO, USA). Fetal bovine serum (FBS) was obtained from Gibco (Grand Island, NY, USA). Dulbecco's Modified Eagle's medium (DMEM), 0.25\% Trypsin solution and the antibiotic reagents (penicillin and streptomycin) were purchased from HyClone Laboratories (Logan, Utah, USA). 1X phosphate-buffered saline (PBS) was purchased from Samchun Pure Chemical Co. (Gyeonggi-do, Korea). TRIzol reagent was purchased from Molecular Research Center, Inc. (Cincinnati, OH, USA). The sets of primers for polymerase chain reaction (PCR) were synthetized by Macrogen (Seoul, Korea), and PCR premix was obtained from Bio-D Inc. (Seoul, Korea). Total and phospho-forms of antibodies were purchased from Cell Signaling Technology (Beverly, MA, USA), and c-Fos and $\beta$-actin were bought from Santa Cruz Biotechnology, Inc. (Dallas, TX, USA). All of the antibodies were diluted 1:2500.

\subsection{Preparation of Pg-EE and Liquid Chromatography-Tandem Mass Spectrometry (LC-MS/MS)}

Pg-EE was prepared from Potentilla glabra var. mandshurica (Maxim.) Hand.-Mazz. $(1 \mathrm{~kg}$ ) by extraction with $95 \%$ ethanol in an ultrasonic extractor (Ultrasonic Cleaner UC-10, UC-20, $400 \mathrm{~W}$ ) for $4 \mathrm{~h}$ at $50{ }^{\circ} \mathrm{C}$ (three times) to yield $21.2 \mathrm{~g}$ [25]. After removal of the solvent under reduced pressure in vacuo, the extract was freeze-dried for $48 \mathrm{~h}$ at $-80^{\circ} \mathrm{C}$, and then stored in a freezer at $-20^{\circ} \mathrm{C}$ until use. The LC-MS/MS analysis was performed on a Xevo G2-XS Q-TOF-LC/ MS (Waters, USA), as reported previously [67]. 


\subsection{Cell Culture}

HaCaT cells were cultured in DMEM media containing 10\% FBS and 1\% penicillin/ streptomycin antibiotics. The cells were maintained in a $5 \% \mathrm{CO}_{2}$ incubator (Thermo Fisher Scientific, Waltham, MA, USA) at $37^{\circ} \mathrm{C}$.

\subsection{Compound Treatment}

The primary stock compound of Pg-EE was dissolved in 100\% dimethyl sulfoxide (DMSO) at a concentration of $100 \mathrm{mg} / \mathrm{mL}$. For each experiment, the primary stock was diluted with media at doses ranging from $12.5 \mu \mathrm{g} / \mathrm{mL}$ to $50 \mu \mathrm{g} / \mathrm{mL}$ for in vitro assays.

\subsection{Cell Viability Assay}

HaCaT cells were spread into 96-well plates at $1 \times 10^{5}$ cell $/ \mathrm{mL}$ in DMEM media. After incubating overnight, Pg-EE was added in a dose-dependent manner. After $24 \mathrm{~h}, 100 \mu \mathrm{L}$ cultured media was removed, and $10 \mu \mathrm{L}$ of $5 \mathrm{mg} / \mathrm{mL}$ MTT solution was injected into each well. After $3 \mathrm{~h}$, MTT stopping solution was added when purple formazan appeared. After $18 \mathrm{~h}$, the absorbance of each well was detected at $570 \mathrm{~nm}$ using a microplate reader (BioTek Instruments Inc., Winooski, VT, USA).

\subsection{Nitric Oxide (NO) Assay}

$\mathrm{HaCaT}$ cells were spread into 96-well plates at a density of $1 \times 10^{6}$ cells $/ \mathrm{mL}$. Then, cells were treated with Pg-EE in a dose-dependent manner and incubated for $24 \mathrm{~h}$. Next, $100 \mu \mathrm{L}$ supernatant was transferred to each well of a fresh 96-well plate. Griess reagent was applied and mixed with these supernatants at the same volume (1:1). Finally, the plates at the absorbance of $540 \mathrm{~nm}$ were read by a multi-plate reader [68]. Then, the NO standard curve $(y=a x+b)$ was used to calculate the NO expression of each group ' $x=(y-b) / a^{\prime}$. In the equation, the $x$ axis represents $\mathrm{NO}$ production, and the $\mathrm{y}$ axis represents absorbance. Finally, the percent of NO production of each group was counted on the basis of the positive control.

\subsection{DPPH Assay}

DPPH is a method that was developed to predict antioxidant activities. The scavenging of DPPH radicals can be used to determine free radical scavenging capacity. First, primary stocks were made of DPPH (3 mM) in methanol, L-Ascorbic Acid (50 mM) in LC-MC grade water, and Pg-EE $(100 \mathrm{mg} / \mathrm{mL})$ in DMSO, respectively. Then, the DPPH stock solution was diluted with LC-MC-grade water to $250 \mu \mathrm{M}$ and Pg-EE was diluted to $20 \mathrm{mg} / \mathrm{mL}$. Next, serial dilutions were made of Pg-EE from $200 \mu \mathrm{g} / \mathrm{mL}$ to $0 \mu \mathrm{g} / \mathrm{mL}$ and fully mixed with $250 \mu \mathrm{M}$ DPPH sister solution at a ratio of 1:100. These mixtures were incubated at $37^{\circ} \mathrm{C}$ for $30 \mathrm{~min}$ before detecting the absorbance at $517 \mathrm{~nm}$.

\subsection{ABTS Radical Scavenging Assay}

ABTS radical scavenging assay is another method that can evaluate antioxidant scavenging effects. Before the experiment, 7.4 mM ABTS and $2.4 \mathrm{mM}$ potassium persulfate were mixed at a ratio of 1:1. Then, the mixture was wrapped with foil and incubated in a $37^{\circ} \mathrm{C}$ incubator for $30 \mathrm{~min}$ until the solution color changed to dark green. Then, the ABTS mixture was diluted until the absorbance was between 0.72 and 0.74 at $730 \mathrm{~nm}$. Next, serial dilutions of Pg-EE were made from $400 \mu \mathrm{g} / \mathrm{mL}$ to 0 . Ascorbic Acid $(50 \mathrm{mM})$ was also mixed with ABTS independently as positive control. After each of the chemicals was diluted in DPBS (Pg-EE from $400 \mu \mathrm{g} / \mathrm{mL}$ to 0 and Ascorbic Acid $50 \mu \mathrm{M}$ ), Pg-EE or ascorbic acid was mixed with ABTS and incubated in a $37^{\circ} \mathrm{C}$ incubator for $30 \mathrm{~min}$. Finally, the absorbance was detected at $730 \mathrm{~nm}$.

\subsection{UVB Irradiation}

HaCaT cells were spread evenly in a 6-well plate at a density of $1 \times 10^{5}$ cells $/ \mathrm{mL}$ with DMEM. Cells were pre-treated with dose-dependent Pg-EE $(0-50 \mu \mathrm{g} / \mathrm{mL})$ for $30 \mathrm{~min}$. Next, 
each well was washed with $1 \mathrm{~mL}$ PBS once and covered the cells by $1 \mathrm{~mL}$ PBS. The plate was exposed in a UVB lamp (Bio-Link BLX-312; Vilber Lourmat, Collégien, France) with an emission wavelength peak of $312 \mathrm{~nm}$ at $30 \mathrm{~mJ} / \mathrm{cm}^{2}$ [69]. After that, the PBS was removed, and the cells were re-treated with Pg-EE for $24 \mathrm{~h}$.

\subsection{Cell Morphology Photography}

HaCaT cells were seeded into 6-well plates at a cell density of $1 \times 10^{5}$ cells $/ \mathrm{mL}$ then pre-treated with Pg-EE (from $50 \mu \mathrm{g} / \mathrm{mL}$ to $0 \mu \mathrm{g} / \mathrm{mL}$ ) for $30 \mathrm{~min}$. Cells were then washed with PBS and irradiated under the UVB lamp. PBS was removed and the cells were retreated with Pg-EE in a dose-dependent manner. After $24 \mathrm{~h}$, photos were taken by using an epifluorescence microscope (Olympus, Tokyo, Japan).

\subsection{Immunoblotting Analysis}

HaCaT cells were seeded into 6-well plates (SPL Life Sciences Co., Gyeonggi-do, Korea) with $10^{5}$ cells / well and treated with Pg-EE with the dose dependency $(0,12.5,25$, or $50 \mu \mathrm{g} / \mathrm{mL}$ ). Then, the cells were lysed with lysis buffer (50 mM pH 7.5 Tris-HCl, $20 \mathrm{mM} \mathrm{NaF}$, $25 \mathrm{mM}$ pH $7.5 \beta$-glycerol phosphate, $120 \mathrm{mM} \mathrm{NaCl}, 2 \% \mathrm{NP}-40$, and phosphatase/protease inhibitors). Cell lysates were centrifuged at the speed of $13,000 \mathrm{rpm}$ for $15 \mathrm{~min}$ at $4{ }^{\circ} \mathrm{C}$ to settled cell debris. Protein concentrations were quantified by Bradford protein assay (BIO-RAD, Hercules, CA, USA). Equal amounts (20 $\mu \mathrm{g}$ protein/lane) of samples were separated by Tris-glycine SDS gels and then transferred to PVDF membranes (Millipore, Billerica, MA, USA). The membranes were blotted with $3 \%$ BSA for $1 \mathrm{~h}$ at room temperature and were then washed with tris-buffered saline (50 mM Tris-Cl, pH 7.5, $150 \mathrm{mM} \mathrm{NaCl})$ and $0.1 \%$ Tween-20 (TBST) three times for 10-min intervals. The membranes were then incubated with primary antibodies overnight at $4{ }^{\circ} \mathrm{C}$. Then, after washing with TBST three times for 10 min each interval, the membranes were incubated in the secondary antibody for $2 \mathrm{~h}$ at room temperature [70]. After that, the membranes were washed with TBST as before. Finally, the membranes were exposed by EzWestLumi plus (ATTO Corporation, Taito-ku, Tokyo, Japan).

4.12. Analysis of mRNA Levels by Semi-Quantitative Reverse Transcription-Polymerase Chain Reaction (RT-PCR) and Quantitative Real-Time Polymerase Chain Reaction (Real-Time PCR)

To evaluate the gene expression of factors related to inflammation and moisturization, $\mathrm{HaCaT}$ cells were seeded, pre-treated with Pg-EE, and then irradiated by UVB as described above. Additionally, SB203580 (a p38 inhibitor), SP600125 (a JNK inhibitor) and U0126 (an ERK inhibitor) were used as positive controls. Total RNA was isolated using TRIzol reagent according to the manufacturer's instructions. Two PCRBIO HS Taq PreMix (PCR Biosystems Ltd., Oxford, UK) were used for RT-PCR, with a cycle of 30 [71]. SYBR Green Premix Ex Taq (Takara Bio, Inc., Shiga, Japan) was used together with the CFX96 Touch Real-Time PCR Detection System (Bio-Rad Laboratories, Inc., Hercules, CA, USA), with the cycle of 40 [72]. The results were normalized to endogenous GAPDH. The results were analyzed using the $2^{-\Delta \Delta C}$ Tethod. The primers for this study are listed in Table 1 . 
Table 1. List of primers synthesized for semi-quantitative RT-PCR and quantitative real-time PCR.

\begin{tabular}{|c|c|c|}
\hline Name & & Sequence $\left(5^{\prime}\right.$ to $\left.3^{\prime}\right)$ \\
\hline \multicolumn{3}{|c|}{ Semi-quantitative RT-PCR } \\
\hline \multirow{2}{*}{$F L G$} & $\mathrm{~F}$ & AGGGAAGATCCAAGAGCCCA \\
\hline & $\mathrm{R}$ & ACTCTGGATCCCCTACGCTT \\
\hline \multirow{2}{*}{ TGM-1 } & $\mathrm{F}$ & GAAATGCGGCAGATGACGAC \\
\hline & $\mathrm{R}$ & AACTCCCCAGCGTCTGATTG \\
\hline \multirow{2}{*}{$H A S-1$} & $\mathrm{~F}$ & CCACCCAGTACAGCGTCAAC \\
\hline & $\mathrm{R}$ & CATGGTGCTTCTGTCGCTCT \\
\hline \multirow{2}{*}{$H A S-2$} & $\mathrm{~F}$ & TTCTTTATGTGACTCATCTGTCTCACCGG \\
\hline & $\mathrm{R}$ & ATTGTTGGCTACCAGTTTATCCAAACG \\
\hline \multirow{2}{*}{$\mathrm{COX}-2$} & $\mathrm{~F}$ & GGGATTTTGGAACGTTGTGAA \\
\hline & $\mathrm{R}$ & CGACATTGTAAGTTGGTGGACTGT \\
\hline \multirow{2}{*}{$I L-1 \beta$} & $\mathrm{F}$ & ATTTGAATTCCCTGGGTGAG \\
\hline & $\mathrm{R}$ & ССТCATCCTGGAAGGTCCAC \\
\hline \multirow{2}{*}{$I L-6$} & $\mathrm{~F}$ & TACCCCCAGGAGAAGATTCC \\
\hline & $\mathrm{R}$ & TTTTCTGCCAGTGCCTCTTT \\
\hline \multirow{2}{*}{ GAPDH } & $\mathrm{F}$ & GCACCGTCAAGGCTGAGAAC \\
\hline & $\mathrm{R}$ & ATGGTGGTGAAGACGCCAGT \\
\hline \multicolumn{3}{|c|}{ Quantitative real-time PCR } \\
\hline \multirow{2}{*}{ FLG } & $\mathrm{F}$ & GGGCACTGAAAGGCAAAAAG \\
\hline & $\mathrm{R}$ & CACСАTAATCATAATCTGCACTACCA \\
\hline \multirow{2}{*}{$H A S-1$} & $\mathrm{~F}$ & CAGCCTGCGATACTGGGTAG \\
\hline & $\mathrm{R}$ & GCCGGTCATCCCCAAAAGTA \\
\hline \multirow{2}{*}{$S O D-1$} & $\mathrm{~F}$ & AAGCGGTGAACCAGTTGTGT \\
\hline & $\mathrm{R}$ & GCCAATGATGGAATGCTCTC \\
\hline \multirow{2}{*}{$N r f-2$} & $\mathrm{~F}$ & ACATCCTTTGGAGGCAAGAC \\
\hline & $\mathrm{R}$ & TCGGGTCATTGTGAGTCAGT \\
\hline \multirow{2}{*}{ GAPDH } & $\mathrm{F}$ & CACTCACGGCAAATTCAACGGC \\
\hline & $\mathrm{R}$ & GACTCCACGACATACTCAGCA \\
\hline
\end{tabular}

F: forward primer, R: reverse Primer.

\subsection{Statistical Analyses}

All the data are presented as means \pm standard deviations, and each experiment was performed as two or three replications. All the immunoblots were measured using ImageJ. Results were analyzed using the Mann-Whitney U test to compare the statistical differences. A $p$-value $<0.05$ was considered statistically significant. All statistical analyses were conducted using SPSS Statistics 25.0 (IBM, Armonk, New York, NY, USA).

\section{Conclusions}

In this study, we evaluated the effects of Pg-EE on skin protection and anti-inflammation under UVB irradiation. Pg-EE can not only enhance the skin barrier and hydration through down-regulating the p38 and ERK signaling pathways, it can also relieve the damage to human keratinocytes by reducing pro-inflammatory factors. Moreover, our data showed that Pg-EE can prevent HaCaT cells from apoptosis induced by UVB irradiation by decreasing the protein levels of Bax and cleaved caspase 3, which can be used as a good ingredient in cosmetics for the prevention of photoaging.

Author Contributions: L.Y., M.-Y.K. and J.Y.C. conceived and designed the experiments; L.Y. performed the experiments; L.Y., M.-Y.K. and J.Y.C. analyzed the data; L.Y., M.-Y.K. and J.Y.C. wrote the paper. All authors have read and agreed to the published version of the manuscript. 
Funding: This research was supported by the Medical Device Technology Development Program (Grant No.: 20008861) funded by the Ministry of Trade, Industry, and Energy (MOTIE), Republic of Korea.

Institutional Review Board Statement: Not applicable.

Informed Consent Statement: Not applicable.

Data Availability Statement: The data used to support the findings of this study are available from the corresponding author upon request.

Conflicts of Interest: The authors have no conflicts of interest to declare.

Sample Availability: Sample of the compound, Pg-EE is available from the authors.

$\begin{array}{ll}\text { Abbreviations } \\ \text { FLG } & \text { Filaggrin } \\ \text { TGM-1 } & \text { Transglutaminase-1 } \\ \text { HAS } & \text { Hyaluronic acid synthase } \\ \text { MAPKs } & \text { Mitogen-activated protein kinases } \\ \text { ERK } & \text { Extracellular signal-regulated kinase } \\ \text { SC } & \text { Stratum corneum } \\ \text { LPS } & \text { Lipopolysaccharides } \\ \text { COX-2 } & \text { Cyclooxygenase-2 } \\ \text { IL-1 } \beta & \text { Interleukin-1 } \beta \\ \text { IL-6 } & \text { Interleukin } 6 \\ \text { TNF- } \alpha & \text { Tumor necrosis factor alpha } \\ \text { MKK } & \text { Mitogen-activated protein kinase } \\ \text { MEK } & \text { MAPK or ERK kinases }\end{array}$

\section{References}

1. Gould, J. Superpowered skin. Nature 2018, 563, S84-S85. [CrossRef] [PubMed]

2. Nestle, F.O.; Di Meglio, P.; Qin, J.-Z.; Nickoloff, B.J. Skin immune sentinels in health and disease. Nat. Rev. Immunol. 2009, 9, 679-691. [CrossRef] [PubMed]

3. Hoerter, J.D.; Bradley, P.; Casillas, A.; Chambers, D.; Denholm, C.; Johnson, K.; Weiswasser, B. Extrafollicular dermal melanocyte stem cells and melanoma. Stem Cells Int. 2012, 2012, 407079. [CrossRef]

4. Bos, J.D.; Kapsenberg, M.L. The skin immune system Its cellular constituents and their interactions. Immunol. Today 1986, 7, 235-240. [CrossRef]

5. Chaudhuri, R.K.; Bojanowski, K. Improvement of hydration and epidermal barrier function in human skin by a novel compound isosorbide dicaprylate. Int. J. Cosmet. Sci. 2017, 39, 518-526. [CrossRef]

6. Eckhart, L.; Zeeuwen, P.L.J.M. The skin barrier: Epidermis vs environment. Exp. Dermatol. 2018, 27, 805-806. [CrossRef]

7. BLANK, I.H. Factors which influence the water content of the stratum corneum. J. Investig. Dermatol. 1952, 18, 433-440. [CrossRef]

8. Wildnauer, R.H.; Bothwell, J.W.; Douglass, A.B. Stratum corneum biomechanical properties. I. Influence of relative humidity on normal and extracted human stratum corneum. J. Investig. Dermatol. 1971, 56, 72-78. [CrossRef]

9. Van Duzee, B.F. The influence of water content, chemical treatment and temperature on the rheological properties of stratum corneum. J. Investig. Dermatol. 1978, 71, 140-144. [CrossRef]

10. Alonso, A.; Meirelles, N.C.; Yushmanov, V.E.; Tabak, M. Water increases the fluidity of intercellular membranes of stratum corneum: Correlation with water permeability, elastic, and electrical resistance properties. J. Investig. Dermatol. 1996, 106, 1058-1063. [CrossRef]

11. Bouwstra, J.A.; De Graaff, A.; Gooris, G.S.; Nijsse, J.; Wiechers, J.W.; Van Aelst, A.C. Water distribution and related morphology in human stratum corneum at different hydration levels. J. Investig. Dermatol. 2003, 120, 750-758. [CrossRef]

12. Sparr, E.; Millecamps, D.; Isoir, M.; Burnier, V.; Larsson, Å.; Cabane, B. Controlling the hydration of the skin though the application of occluding barrier creams. J. R. Soc. Interface 2013, 10, 20120788. [CrossRef]

13. Kim, M.K.; Kim, E.J.; Cheng, Y.; Shin, M.H.; Oh, J.H.; Lee, D.H.; Chung, J.H. Inhibition of DNA methylation in the COL1A2 promoter by anacardic acid prevents UV-induced decrease of type I procollagen expression. J. Investig. Dermatol. 2017, 137, 1343-1352. [CrossRef]

14. Cavinato, M.; Koziel, R.; Romani, N.; Weinmüllner, R.; Jenewein, B.; Hermann, M.; Dubrac, S.; Ratzinger, G.; Grillari, J.; Schmuth, M.; et al. UVB-induced senescence of human dermal fibroblasts involves impairment of proteasome and enhanced autophagic activity. J. Gerontol. Ser. A Biomed. Sci. Med. Sci. 2017, 72, 632-639. [CrossRef] [PubMed] 
15. Cavinato, M.; Jansen-Dürr, P. Molecular mechanisms of UVB-induced senescence of dermal fibroblasts and its relevance for photoaging of the human skin. Exp. Gerontol. 2017, 94, 78-82. [CrossRef]

16. Lin, P.; Hwang, E.; Ngo, H.T.T.; Seo, S.A.; Yi, T.H. Sambucus nigra L. ameliorates UVB-induced photoaging and inflammatory response in human skin keratinocytes. Cytotechnology 2019, 71, 1003-1017. [CrossRef] [PubMed]

17. Cavinato, M.; Waltenberger, B.; Baraldo, G.; Grade, C.V.C.; Stuppner, H.; Jansen-Dürr, P. Plant extracts and natural compounds used against UVB-induced photoaging. Biogerontology 2017, 18, 499-516. [CrossRef] [PubMed]

18. Trautinger, F. Mechanisms of photodamage of the skin and its functional consequences for skin ageing. Clin. Exp. Dermatol. 2001, 26, 573-577. [CrossRef]

19. Lin, T.Y.; Wu, P.Y.; Hou, C.W.; Chien, T.Y.; Chang, Q.X.; Wen, K.C.; Lin, C.Y.; Chiang, H.M. Protective effects of sesamin against UVB-induced skin inflammation and photodamage in vitro and in vivo. Biomolecules 2019, 9, 479. [CrossRef]

20. Pal, H.C.; Athar, M.; Elmets, C.A.; Afaq, F. Fisetin inhibits UVB-induced cutaneous inflammation and activation of PI3K/AKT/NFKB signaling pathways in SKH-1 hairless mice. Photochem. Photobiol. 2015, 91, 225-234. [CrossRef]

21. Kuwano, T.; Kawano, S.; Kagawa, D.; Yasuda, Y.; Inoue, Y.; Murase, T. Dietary intake of glucono- $\delta$-lactone attenuates skin inflammation and contributes to maintaining skin condition. Food Funct. 2018, 9, 1524-1531. [CrossRef] [PubMed]

22. Kuo, Y.H.; Wu, P.Y.; Chen, C.W.; Lin, P.; Wen, K.C.; Lin, C.Y.; Chiang, H.M. N-(4-bromophenethyl) caffeamide protects skin from UVB-induced inflammation through MAPK/IL-6/NF- $\mathrm{kB}$-dependent signaling in human skin fibroblasts and hairless mouse skin. Molecules 2017, 22, 1639. [CrossRef]

23. Lou, L.; Li, Y.; Li, Y. Chemical constituents of the essential oil from Potentilla glabra var. mandshurica Maxim. J. Lanzhou Univ. Nat. Sci. 2004, 40, 58-60.

24. Hu, Y.L.; Wang, W.Y.; Li, Y.W.; Xu, L.J.; Peng, Y. Research progress in Yaowang tea. Drugs Clin. 2013, 28, $236-241$.

25. Kim, H.; Shin, K.K.; Kim, H.G.; Jo, M.; Kim, J.K.; Lee, J.S.; Choung, E.S.; Li, W.Y.; Lee, S.W.; Kim, K.H.; et al. Src/nf-kb-targeted anti-inflammatory effects of Potentilla glabra var. Mandshurica (maxim.) hand.-mazz. ethanol extract. Biomolecules 2020, 10, 648. [CrossRef]

26. Tobin, D.J. Introduction to skin aging. J. Tissue Viabil. 2017, 26, 37-46. [CrossRef] [PubMed]

27. Plumb, J.A. Cell sensitivity assays: The MTT assay. Methods Mol. Med. 1999, 28, 25-30. [CrossRef]

28. Katsuki, S.; Arnold, W.; Mittal, C.; Murad, F. Stimulation of guanylate cyclase by sodium nitroprusside, nitroglycerin and nitric oxide in various tissue preparations and comparison to the effects of sodium azide and hydroxylamine. J. Cyclic Nucleotide Res. 1977, 3, 23-35.

29. Cole, P. The safe use of sodium nitroprusside. Anaesthesia 1978, 33, 473-477. [CrossRef] [PubMed]

30. Pyrzynska, K.; Pękal, A. Application of free radical diphenylpicrylhydrazyl (DPPH) to estimate the antioxidant capacity of food samples. Anal. Methods 2013, 5, 4288-4295. [CrossRef]

31. Miller, N.J.; Rice-Evans, C.A. Factors influencing the antioxidant activity determined by the ABTS ${ }^{+}$radical cation assay. Free Radic. Res. 1997, 26, 195-199. [CrossRef]

32. Cadet, J.; Douki, T.; Pouget, J.P.; Ravanat, J.L.; Sauvaigo, S. Effects of UV and visible radiations on cellular DNA. Curr. Probl. Dermatol. 2001, 29, 62-73. [CrossRef] [PubMed]

33. Aufiero, B.M.; Talwar, H.; Young, C.; Krishnan, M.; Hatfield, J.S.; Lee, H.K.; Wong, H.K.; Hamzavi, I.; Murakawa, G.J. Narrow-band UVB induces apoptosis in human keratinocytes. J. Photochem. Photobiol. B Biol. 2006, 82, 132-139. [CrossRef]

34. Korsmeyer, S.J.; Shutter, J.R.; Veis, D.J.; Merry, D.E.; Oltvai, Z.N. Bcl-2/Bax: A rheostat that regulates an anti-oxidant pathway and cell death. Semin. Cancer Biol. 1993, 4, 327-332. [PubMed]

35. Yin, X.M.; Oltvai, Z.N.; Korsmeyer, S.J. BH1 and BH2 domains of Bcl-2 are required for inhibition of apoptosis and heterodimerization with Bax. Nature 1994, 369, 321-323. [CrossRef]

36. Khodapasand, E.; Jafarzadeh, N.; Farrokhi, F.; Kamalidehghan, B.; Houshmand, M. Is Bax/Bcl-2 ratio considered as a prognostic marker with age and tumor location in colorectal cancer? Iran. Biomed. J. 2015, 19, 69-75. [CrossRef]

37. Hector, S.; Prehn, J.H.M. Apoptosis signaling proteins as prognostic biomarkers in colorectal cancer: A review. Biochim. Biophys. Acta-Rev. Cancer 2009, 1795, 117-129. [CrossRef]

38. Mohan, S.; Abdelwahab, S.I.; Kamalidehghan, B.; Syam, S.; May, K.S.; Harmal, N.S.M.; Shafifiyaz, N.; Hadi, A.H.A.; Hashim, N.M.; Rahmani, M.; et al. Involvement of NF-kB and Bcl2/Bax signaling pathways in the apoptosis of MCF7 cells induced by a xanthone compound pyranocycloartobiloxanthone A. Phytomedicine 2012, 19, 1007-1015. [CrossRef] [PubMed]

39. Mcllwain, D.R.; Berger, T.; Mak, T.W. Caspase functions in cell death and disease. Cold Spring Harb. Perspect. Biol. 2015, 7, a008656. [CrossRef] [PubMed]

40. Choi, E.; Yi, Y.S.; Lee, J.; Park, S.H.; Kim, S.; Hossain, M.A.; Jang, S.G.; Choi, Y.I.; Park, K.J.; Kim, D.S.; et al. Anti-apoptotic and anti-inflammatory activities of edible fresh water algae Prasiola japonica in UVB-irradiated skin keratinocytes. Am. J. Chin. Med. 2019, 47, 1853-1868. [CrossRef] [PubMed]

41. Wang, P.W.; Cheng, Y.C.; Hung, Y.C.; Lee, C.H.; Fang, J.Y.; Li, W.T.; Wu, Y.R.; Pan, T.L. Red raspberry extract protects the skin against UVB-induced damage with antioxidative and anti-inflammatory properties. Oxid. Med. Cell. Longev. 2019, $2019,9529676$. [CrossRef]

42. Franco, L.; Marchena, A.; Rodríguez, A. Skin health properties of lycopene and melatonin. J. Dermatol. Ski. Sci. 2021, 3, 26-29. [CrossRef] 
43. Rumzhum, N.N.; Ammit, A.J. Cyclooxygenase 2: Its regulation, role and impact in airway inflammation. Clin. Exp. Allergy 2016, 46, 397-410. [CrossRef]

44. Ferrucci, L.; Fabbri, E. Inflammageing: Chronic inflammation in ageing, cardiovascular disease, and frailty. Nat. Rev. Cardiol. 2018, 15, 505-522. [CrossRef] [PubMed]

45. Kondylis, V.; Kumari, S.; Vlantis, K.; Pasparakis, M. The interplay of IKK, NF- $\mathrm{KB}$ and RIPK 1 signaling in the regulation of cell death, tissue homeostasis and inflammation. Immunol. Rev. 2017, 277, 113-127. [CrossRef] [PubMed]

46. Cabanillas, B.; Novak, N. Atopic dermatitis and filaggrin. Curr. Opin. Immunol. 2016, 42, 1-8. [CrossRef] [PubMed]

47. Kim, S.Y.; Chung, S.I.; Yoneda, K.; Steinert, P.M. Expression of transglutaminase 1 in human epidermis. J. Investig. Dermatol. 1995, 104, 211-217. [CrossRef] [PubMed]

48. Herman, M.L.; Farasat, S.; Steinbach, P.J.; Wei, M.H.; Toure, O.; Fleckman, P.; Blake, P.; Bale, S.J.; Toro, J.R. Transglutaminase-1 gene mutations in autosomal recessive congenital ichthyosis: Summary of mutations(including 23 novel) and modeling of TGase-1. Hum. Mutat. 2009, 30, 537-547. [CrossRef]

49. Farasat, S.; Wei, M.H.; Herman, M.; Liewehr, D.J.; Steinberg, S.M.; Bale, S.J.; Fleckman, P.; Toro, J.R. Novel transglutaminase-1 mutations and genotypephenotype investigations of 104 patients with autosomal recessive congenital ichthyosis in the USA. J. Med. Genet. 2009, 46, 103-111. [CrossRef]

50. Siiskonen, H.; Oikari, S.; Pasonen-Seppänen, S.; Rilla, K. Hyaluronan synthase 1: A mysterious enzyme with unexpected functions. Front. Immunol. 2015, 6, 43. [CrossRef] [PubMed]

51. Malaisse, J.; Bourguignon, V.; De Vuyst, E.; Lambert De Rouvroit, C.; Nikkels, A.F.; Flamion, B.; Poumay, Y. Hyaluronan metabolism in human keratinocytes and atopic dermatitis skin is driven by a balance of hyaluronan synthases 1 and 3. J. Investig. Dermatol. 2014, 134, 2174-2182. [CrossRef]

52. Yi, Y.; Gu, L.; Liu, S.; Jin, F. Magnesia reactivity on activating efficacy for ground granulated blastfurnace slag for soft clay stabilisation. Appl. Clay Sci. 2016, 126, 57-62. [CrossRef]

53. Lee, D.E.; Ayoub, N.; Agrawal, D.K. Mesenchymal stem cells and cutaneous wound healing: Novel methods to increase cell delivery and therapeutic efficacy. Stem Cell Res. Ther. 2016, 7, 1-8. [CrossRef] [PubMed]

54. Kaidbey, K.H.; Agin, P.P.; Sayre, R.M.; Kligman, A.M. Photoprotection by melanin-A comparison of black and Caucasian skin. J. Am. Acad. Dermatol. 1979, 1, 249-260. [CrossRef]

55. Han, A.; Chien, A.L.; Kang, S. Photoaging. Dermatol. Clin. 2014, 32, 291-299. [CrossRef]

56. Lam, S.M. A new paradigm for the aging face. Textb. Aging Ski. 2010, 27, 1139-1145. [CrossRef]

57. Gordon, J.R.S.; Brieva, J.C. Unilateral dermatoheliosis. N. Engl. J. Med. 2012, 366, e25. [CrossRef] [PubMed]

58. Riahi, R.R.; Bush, A.E.; Cohen, P.R. Topical retinoids: Therapeutic mechanisms in the treatment of photodamaged skin. Am. J. Clin. Dermatol. 2016, 17, 265-276. [CrossRef]

59. Griffiths, C.E.M. The role of retinoids in the prevention and repair of aged and photoaged skin. Clin. Exp. Dermatol. 2001, 26, 613-618. [CrossRef]

60. Darlenski, R.; Surber, C.; Fluhr, J.W. Topical retinoids in the management of photodamaged skin: From theory to evidence-based practical approach. Br. J. Dermatol. 2010, 163, 1157-1165. [CrossRef]

61. Mukherjee, S.; Date, A.; Patravale, V.; Korting, H.C.; Roeder, A.; Weindl, G. Retinoids in the treatment of skin aging: An overview of clinical efficacy and safety. Clin. Interv. Aging 2006, 1, 327-348. [CrossRef] [PubMed]

62. Poon, F.; Kang, S.; Chien, A.L. Mechanisms and treatments of photoaging. Photodermatol. Photoimmunol. Photomed. 2015, 31, 65-74. [CrossRef] [PubMed]

63. Choi, J.-H.; Oh, S.-K. Studies on the anti-aging action of Korean ginseng. Korean J. Food Sci. Technol. 1985, 17, 506-515.

64. Cui, X.; Ma, Y.; Wang, H.; Huang, J.; Li, L.; Tang, J.; Cheng, B. The anti-photoaging effects of pre- and post-treatment of platelet-rich plasma on UVB-damaged HaCaT keratinocytes. Photochem. Photobiol. 2021, 97, 589-599. [CrossRef]

65. Chiu, L.Y.; Wu, N.L.; Hung, C.F.; Bai, P.; Dai, Y.S.; Lin, W.W. PARP-1 involves in UVB-induced inflammatory response in keratinocytes and skin injury via regulation of ROS-dependent EGFR transactivation and p38 signaling. FASEB J. 2021, 35, e21393. [CrossRef]

66. Ko, H.J.; Kim, J.; Ahn, M.; Kim, J.H.; Lee, G.S.; Shin, T. Ergothioneine alleviates senescence of fibroblasts induced by UVB damage of keratinocytes via activation of the Nrf2/HO-1 pathway and HSP70 in keratinocytes. Exp. Cell Res. 2021, 400, 112516. [CrossRef]

67. Kim, J.K.; Choi, E.; Hong, Y.H.; Kim, H.; Jang, Y.J.; Lee, J.S.; Choung, E.S.; Woo, B.Y.; Hong, Y.D.; Lee, S.; et al. Syk/NF-kB-targeted anti-inflammatory activity of Melicope accedens (Blume) T.G. Hartley methanol extract. J. Ethnopharmacol. 2021, $271,113887$. [CrossRef]

68. Baik, J.S.; Seo, Y.N.; Yi, J.M.; Rhee, M.H.; Park, M.T.; Kim, S.D. Ginsenoside-Rp1 inhibits radiation-induced effects in lipopolysaccharide-stimulated J774A.1 macrophages and suppresses phenotypic variation in CT26 colon cancer cells. J. Ginseng Res. 2020, 44, 843-848. [CrossRef]

69. Park, Y.S.; Lee, J.E.; Park, J.I.; Myung, C.H.; Lim, Y.H.; Park, C.K.; Hwang, J.S. Inhibitory mechanism of ginsenoside Rh3 on granulocyte-macrophage colony-stimulating factor expression in UV-B-irradiated murine SP-1 keratinocytes. J. Ginseng Res. 2020, 44, 274-281. [CrossRef]

70. Lorz, L.R.; Kim, D.; Kim, M.Y.; Cho, J.Y. Panax ginseng-derived fraction BIOGF1K reduces atopic dermatitis responses via suppression of mitogen-activated protein kinase signaling pathway. J. Ginseng Res. 2020, 44, 453-460. [CrossRef] 
71. Lee, J.O.; Kim, J.H.; Kim, S.; Kim, M.Y.; Hong, Y.H.; Kim, H.G.; Cho, J.Y. Gastroprotective effects of the nonsaponin fraction of Korean Red Ginseng through cyclooxygenase-1 upregulation. J. Ginseng Res. 2020, 44, 655-663. [CrossRef] [PubMed]

72. Rho, T.; Jeong, H.W.; Hong, Y.D.; Yoon, K.; Cho, J.Y.; Yoon, K.D. Identification of a novel triterpene saponin from Panax ginseng seeds, pseudoginsenoside RT8, and its antiinflammatory activity. J. Ginseng Res. 2020, 44, 145-153. [CrossRef] [PubMed] 